Phys sp p20 f $(22,5$

INTERNATIONALE VEREINIGUNG FÜR THEORETISCHE UND ANGEWANDTE LIMNOLOOGE INTERNATIONAL ASSOCIATION
OFTHEORETICAL AND APPLIE LIMNOLOGY
ASSOCIATION INTERNATIONALE
DE LIMNOLOGIE THEOORIQUE ET APPLIQUEE

VERHANDLUNGEN P PROCEEDINGS TRAVAUX VOE. 22

CONGRESS IN FRANCE 19.83

EDITED FOR THE ASSOCIATION BY V. SLÁDEČEK

Part 5

World List abbreviation? Verh. int Ver. Limpol DIN 1502 Ablikurzung Verh. Internat Verein Limnot.

\title{
STUTTGART 1985
}

E. SCHWEIZERBART'SCHE VERLAGSBUCHHANDLUNG (NÄGELE Y OBERMILLER)

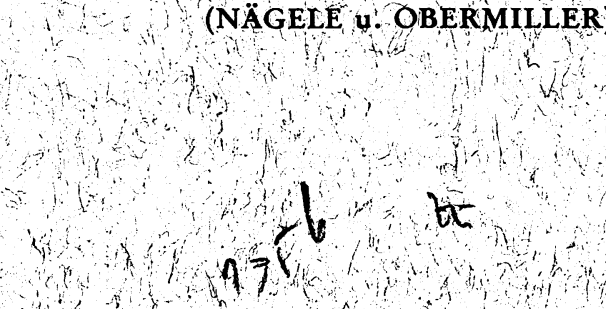




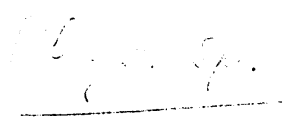

\section{Contents of Part 5}

\section{Ecology of Aquatic Organisms. 1. Microbes (continued)}

KATO, K.: A concept on the structure and function of bacterial community in aquatic eco-

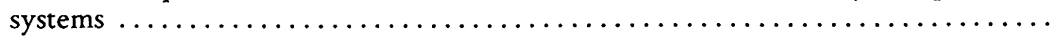

Ochial, M. \& Nakajima, T.: Decomposition of organic matter extracted from sessile mi-

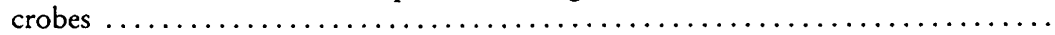

Wissmar, R. C., Lilley, M. D. \& Angelis, M. De: Nitrification and the inhibition of nitrite

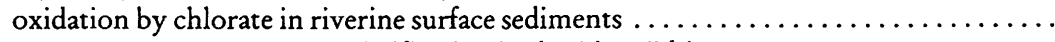

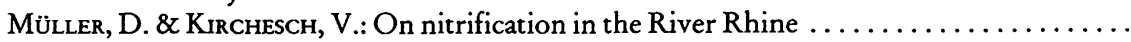

Holder-Frankin, M. A.: Mathematical methods for revealing the influence of the environ-

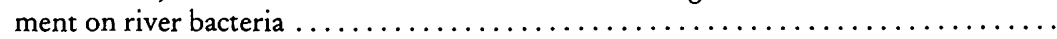

ANTONIETTI, R.: The measure of ATP flows in microbial communities: First results ........

STÖскLI, A.: The role of bacteria and algae in phosphorus regeneration using linked contin-

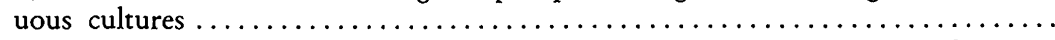

WOOd-EgGeNSCHWILER, S. \& BärLOCHER, F.: Geographical distribution of Ingoldian fungi ...

ROSSET, J. \& BÄRLOCHER, F.: Transplant experiments with aquatic hyphomycetes . . . . . . . .

\section{Ecology of Aquatic Organisms. 2. Algae and Other Plants}

Klemer, A. R., Pierson, D. C. \& Whiteside, M. C.: Blue-green algal (cyanobacterial) nutri-

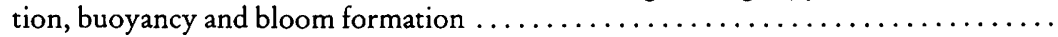

WARD, A. K.: Factors affecting distribution of Nostoc in Cascade Mountain streams of Western Oregon, U.S.A.

Casanova, J. \& Lafont, R.: Les cyanophycées encroûtantes des eaux courantes du Var

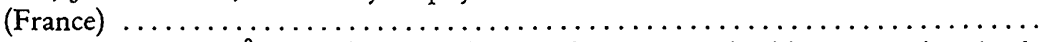

Melvasalo, T. \& Niemi, $\AA$.: The fixation of molecular nitrogen by blue-green algae in the

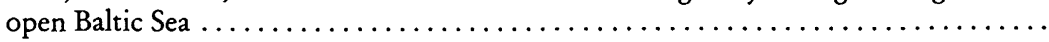

AHLGREN, G.: Growth of Microcystis wesenbergii in batch and chemostat cultures . . . . . . . .

KAPPERS, F. I.: Growth kinetics of the cyanobacterium Microcystis aeruginosa . . . . . . . . .

Zevenboom, W., Latuhinin, M. J. \& MUR, L. R.: Diel-periodicity in photosynthesis of cyanobacteria in continuous cultures and the role of carbohydrates (Abstract) .........

Kristiansen, J.: Occurrence of scale-bearing Chrysophyceae in a eutrophic Danish lake .....

Falkowski, P. G., Dubinsky, Z. \& Santostefano, G.: Light-enhanced dark respiration in

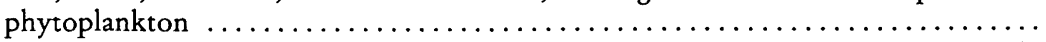

Kadrubowska, J. Z.: Untersuchungen der Stetigkeit der Diatomeengesellschaften aus der Salzquelle, den Limnokrenen und dem Moortümpel ....................

Yoshitake, S. \& Fuxushima, H.: Interrelation between epilithic or drifting algae and algae contained in the digestive tracts of some aquatic insects $\ldots \ldots \ldots \ldots \ldots \ldots \ldots \ldots$

Hickel, B.: The population structure of Ceratium in a small eutrophic lake . . . . . . . . . .

Berman, T. \& Dubinsky, Z.: The autecology of Peridinium cinctum fa. westii from Lake Kin-

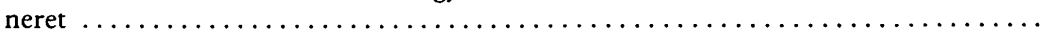

HAPPEY-WOOD, C. M.: Growth characteristics of micro-green algae ..................

LEHMAN, J. T.: Cell quotas of nutrients in phytoplankton established by X-ray analysis ......

Olsen, Y., Jensen, A. \& ReinerTsen, H.: ATP changes in P-starved algae as a measure of

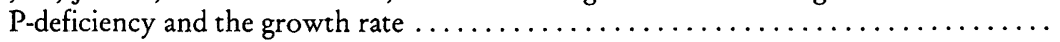

Rosemarin, A. S.: Reproductive strategy in the filamentous green alga Cladophora glomerata (L.) Kürz. - an explanation for its widespread distribution ...................

HiLlebrand, H.: Growth control of filamentous algae by light and temperature (Abstract) ..

GuERLESQuin, M.: Bilan et répartition de la flore des Charophycées dans les Antilles .........

LнотsкÝ, O.: The time factor in the evaluation of algal communities ...............

FLIK, B. J. G.: Measurements of time dependent inhibition and recovery of a laboratory culture of Chlorella sp. at various light intensities .........................

Jensen, L. M., Jørgensen, N. O. G. \& SøndergaArd, M.: Specific activity. Significance in estimating release rates of extracellular dissolved organic carbon (EOC) by algae ...... 
BROBERG, B.: Biological availability of different fractions of dissolved phosphorus in two na-

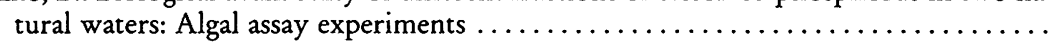

Kairesalo, T., Koskimies, I., Lehtovaara, A. \& Vähä-Pinkiö, I.: Consequences of fertilization within a littoral Equisetum fluviatile L. stand in Lake Pääjärvi, southern Finland . .

KeELEY, J. E.: The role of CAM in the carbon economy of the submerged-aquatic Isoetes bo-

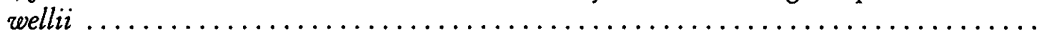

Balls, H., Moss, B. \& Irvine, K.: The effects of high nutrient loading on interactions be-

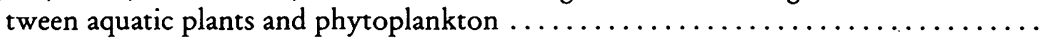

BOAR, R. R. \& СROOK, C. E.: Investigations into the causes of reedswamp regression in the

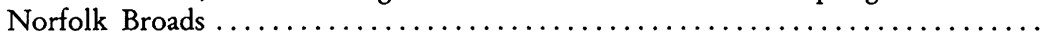

Rørslett, B., Berge, D. \& Johansen, S. W.: Mass invasion of Elodea canadensis in a mesotrophic, South Norwegian lake - impact on water quality .................

RøRSLETT, B.: Regulation impact on submerged macrophytes in the oligotrophic lakes of Se-

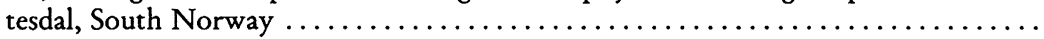

VeLDE, G. vaN DeR \& HeIJDEN, L. A. vaN DER: Initial decomposition of floating leaves in Nymphoides peltata (GMEL.) O. KunTZE (Menyanthaceae) in relation to their age, with

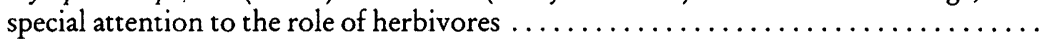

BRock, T. C. M.: Aspects of production and decomposition of Nymphoides peltata (GMEL.)

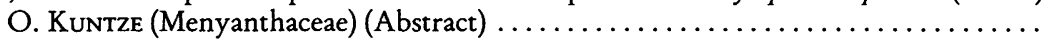

Galanti, G. \& GuIlizzoni, P.: Nutrient uptake by a floating-leaved aquatic plant (Trapa na-

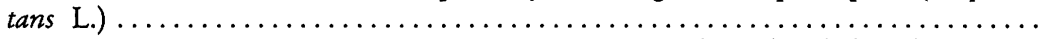

Lachavanne, J.-B., Juge, R., Noetzlin, A. \& Perfetta, J.: Ecological and chorological study of Swiss lake aquatic plants: A basic method to determine the bioindicator value of

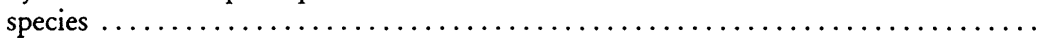

LaChavanNe, J.-B.: The influence of accelerated eutrophication on the macrophytes of Swiss

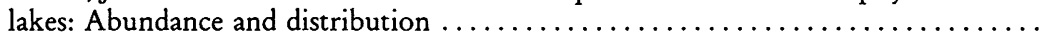

GranéLI, W.: Biomass response after nutrient addition to natural stands of reed, Phragmites

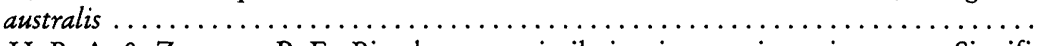

PrINS, H. B. A. \& Z ANSTRA, P. E.: Bicarbonate assimilation in aquatic angiosperms. Signifi-

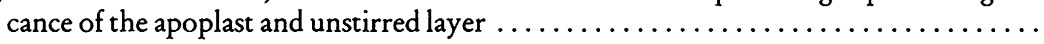

\section{Ecology of Aquatic Organisms. 3. Animals}

Konopacka, A. \& SICIŃSKI, J.: Macrofauna inhabiting the colonies of the sponge Spongilla la-

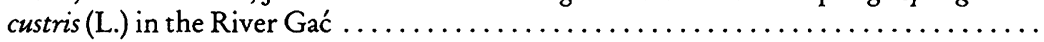

Herrmann, J.: Reproductive strategies in Dendrocoelum lacteum (Turbellaria) - comparisons between Swedish and British populations

RutTNER-Kolisko, A.: Results of individual cross-mating experiments in three distinct

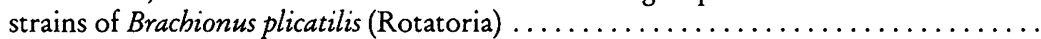

Hofmann, W.: Dynamics of vertical zooplankton community structure in the Plußsee:

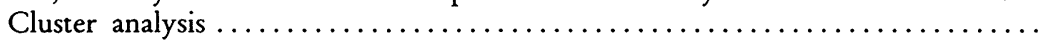

MAY, L.: The use of procaine hydrochloride in the preparation of rotifer samples for count-

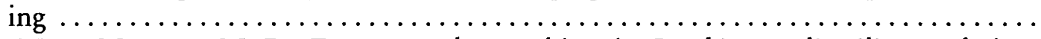

SerRa, M. \& Miracle, M. R.: Enzyme polymorphism in Brachionus plicatilis populations

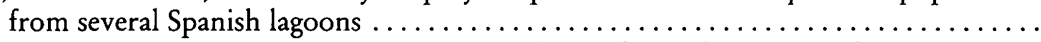

GilberT, J. J. \& S TEMBERGER, R. S.: Prey capture in the rotifer Asplanchna girodi ............

STENSON, J. A. E.: Interactions between pelagic metazoan and protozoan zooplankton: an

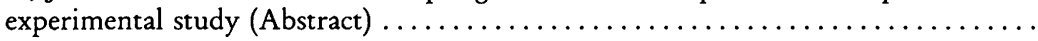

Clément, P., luciani, A., Cornillac, A., Chassé, J. L., Coulon, P. Y., Charras, J. P., NOUGARET, M. \& FourNier, A.: Un système de trajectographie automatique pour étudier la nage d'animaux planctoniques (Rotifères, miracidiums de Plathelminthes etc.) .

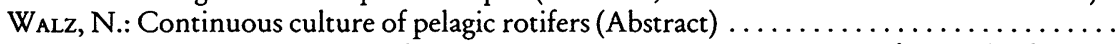

Henrikson, L., Nyman, H. G., Oscarson, N. G. \& Stenson, J. A. E.: Changes in the zooplankton community after lime treatment of an acidified lake $\ldots \ldots \ldots \ldots \ldots \ldots$.

SCHIEMER, F.: Bioenergetic niche differentiation of aquatic invertebrates ...............

LAFONT, M. \& JUGET, J.: Les Oligochètes de quelques lacs français: propositions en vue de leur utilisation pratique pour apprécier l'état biologique des sédiments profonds ...... 
Thiery, A.: Ponte et ultrastructure de l'oeuf chez Triops granarius LucAs (Crustacea, No-

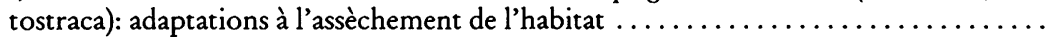

HILDREw, A. G.: Life history characteristics of fairy shrimps (Anostraca) from tropical rain-

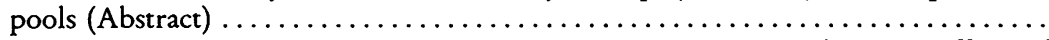

Bernardi, R. DE, Giussani, G., Manca, M., RufFoni, T. \& Savia, A.: Laboratory effects of three species of Daphnia on Scenedesmus population growth and on selected environ-

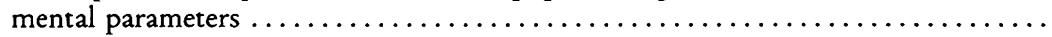

Bernardi, R. De, Giussani, G., Pedretti, E. L. \& Ruffoni, T.: Population dynamics of pelagic cladocerans in three lakes with different trophy $\ldots \ldots \ldots \ldots \ldots \ldots \ldots \ldots \ldots$

Kersting, K.: Properties of an aquatic micro-ecosystem. V. Ten years of observations of the

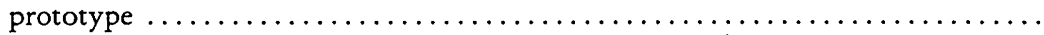

INFANTE, A. \& LITT, A. H.: A comparison of the nutritive value of some algae for Daphnia in

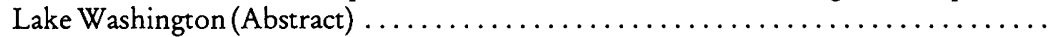

TAYLOR, B. E. \& GABRIEL, W.: Reproductive strategies of two similar Daphnia species .......

JENSEN, J. W.: The morphology and ecology of coexisting Daphnia galeata galeata SARS and

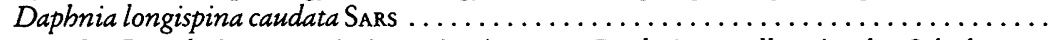

Wolf, H. G.: Population genetic investigations on Daphnia cucullata in the Schöhsee at

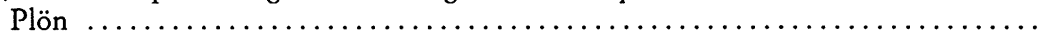

TAYLOR, W. W. \& GERRING, S. D.: Effect of rainbow trout predation on the production of its prey, Daphnia pulex.

VAGA, R. M., Culver, D. A. \& MunCH, C. S.: The fecundity ratios of Daphnia and Bosmina

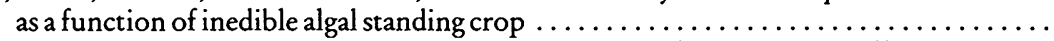

Levitan, C., Kerfoot, W. C. \& DeMott, W. R.: Ability of Daphnia to buffer trout lakes

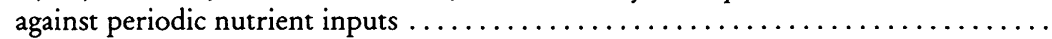

ThrelkeLD, $\mathrm{S}$. T.: Egg degeneration and mortality in cladoceran populations .............

Herzig, A.: Resting eggs - a significant stage in the life cycle of crustaceans Leptodora kindti

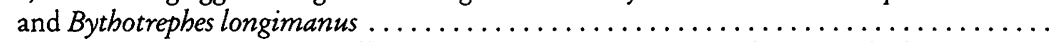

Berner, D. B.: Morphological differentiation among species in the Ceriodaphnia cornuta

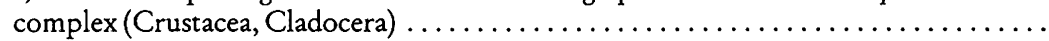

GopHEN, M.: Effect of fish predation on size class distribution of cladocerans in Lake Kinne-

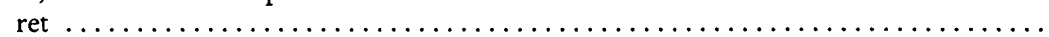

Duncan, A., LAMpert, W. \& Rocha, O.: Carbon weight on length regressions of Daphnia spp. grown at threshold food concentrations $\ldots \ldots \ldots \ldots \ldots \ldots \ldots \ldots \ldots \ldots \ldots \ldots \ldots$

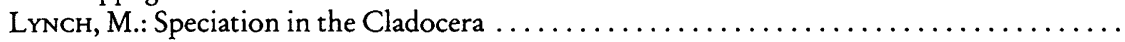

Langeland, A., Koksvik, J. I. \& Olsen, Y.: Post-embryonic development and growth rates of Daphnia pulex DE GEER and Daphnia galeata SARs under natural food conditions ....

Larsson, P., Johnsen, G. \& Steigen, A. L.: An experimental study of the summer decline in

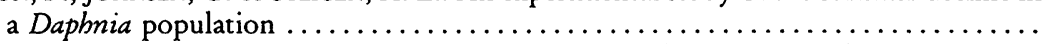

MülleR, H.: The niches of Bosmina coregoni and Bosmina longirostris in the ecosystem of Lake Constance

Косн, K. D. \& MeIJering, M. P. D.: On the distribution and ecology of Cyclopidae on Bear

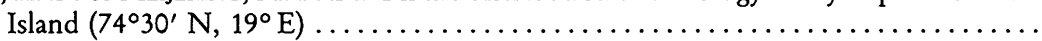

WyngaARD, G. A., Russek, E. \& Allan, J. D.: Life history variation in north temperate and subtropical populations of Mesocyclops edax (Crustacea: Copepoda) ............

Elgmork, K.: Prolonged life cycles in the planktonic copepod Cyclops scutifer SARS .........

Riera, T. \& Estrada, M.: Dimensions and allometry in Tropocyclops prasinus. Empirical re-

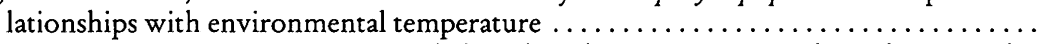

Gabriel, W. \& LAMPERT, W.: Can cannibalism be advantageous in cyclopoids? A mathe-

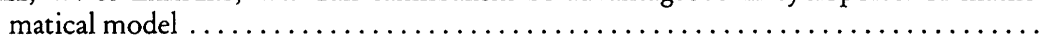

JAMIESON, C. D. \& Burns, C. W.: Copepod distribution patterns: Life history adaptations to

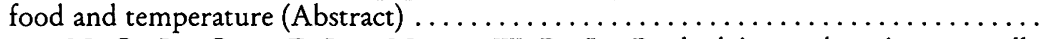

Hairston, N. G., Jr., Olds, E. J. \& MunNs, W. R., Jr.: Bet-hedging and environmentally

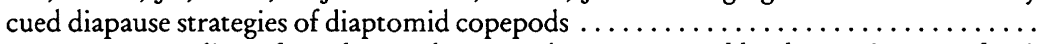

Hartmann, H. J.: Feeding of Daphnia pulicaria and Diaptomus ashlandi on mixtures of uni-

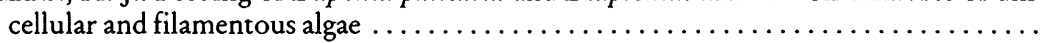

Rujkeboer, M., Flik, B. J. G. \& Ringelberg, J.: Aspects of colour dimorphism in Acanthodiaptomus denticornis found in two French crater lakes (Abstract) ...............

3062

3072

3076

3083

3088

3099

3104

3109

3116

3124

3131

3137

3144

3149

3154

3159

3164

3169

3170

3178 
Pryasiri, S.: Dependence of food on growth and development of two freshwater tropical and

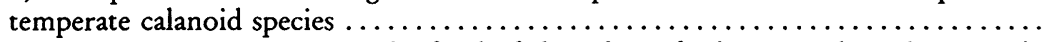

Wong, C. K. \& CHOw-Fraser, P.: The food of three large freshwater calanoid copepods: Limnocalanus macrurus SARS, Epischura lacustris FORBES, and Senecella calanoides JU-

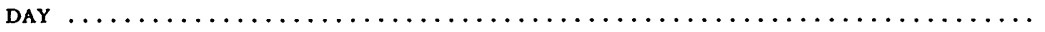

CHOw-Fraser, P. \& Wong, C. K.: Herbivorous feeding of three large freshwater calanoid copepods, Limnocalanus macrurus SARs, Senecella calanoides JUDAY and Epischura lacu-

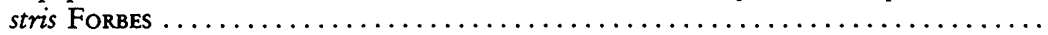

Sото, D.: Experimental evaluation of copepod interactions .....................

Saint-Jean, L. \& Pagano, M.: Influence de la salinité, de la température, et de la concentration des particules en suspension, sur la croissance et la production d'oeufs chez Acartia clausi en lagune Ebrié (Côte d'Ivoire) (Abstract) .......................

Pont, D.: Production secondaire du cyclopoïde Acanthocyclops robustus (G. O. SARs) dans les

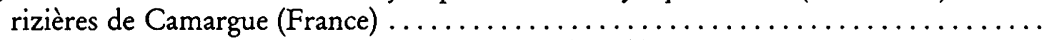

Folt, C. L.: Predator efficiencies and prey risks at high and low prey densities . . . . . . . .

Ramcharan, C. W., Sprules, W. G. \& Nero, R. W.: Notes on the tactile feeding behaviour

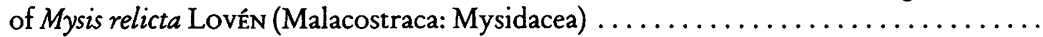

Ginet, R.: Présence de l'amphipode hypogé Niphargus dans certains lacs alpins de haute-

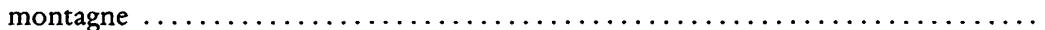

SwIFT, M. C.: Growth and reproduction of Palaemonetes paludosus in a coastal North Caro-

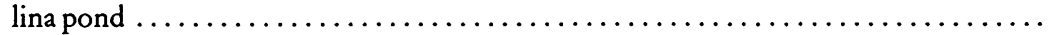

Fidalgo, M. L.: About the assimilation efficiency of the freshwater shrimp, Atyaephyra des-

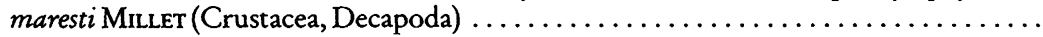

WINKEL, E. H. TEN: The influence of predation by the water mite Hygrobates nigromaculatus

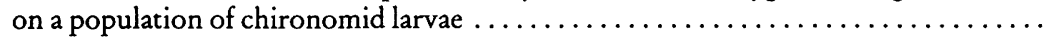

ALLAN, J. D.: The production ecology of Ephemeroptera in a Rocky Mountain stream ......

StatzNeR, B. \& Mogel, R.: An example showing that drift net catches of stream mayflies (Baetis spp., Ephemeroptera, Insecta) do not increase during periods of higher sub-

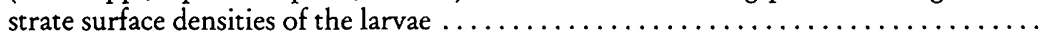

Maquet, B. \& Rosillon, D.: Cycle de développement de l'éphéméroptère Baetis rhodani PICTET dans deux rivières salmonicoles belges: la Rulles et le Samson . . . ............

Camprent, I. C.: Dietary habits of Australian siphlonurid and oligoneuriid ephemeropteran

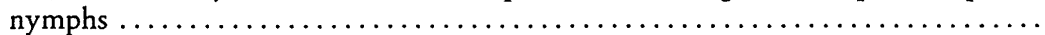

RIEDERER, R. A. A.: Emergence behaviour of some mayflies and stoneflies (Insecta: Ephe-

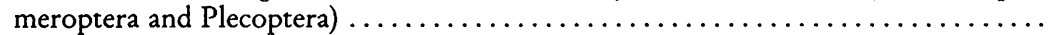

Ban, Y., Shibata, S. \& Ishikawa, M.: Remarks on the life cycle of the water scorpion, Nepa

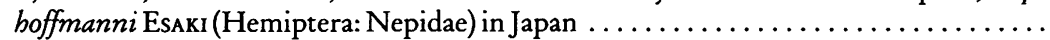

Petersen, L. B.-M.: Food preferences in three species of Hydropsyche (Trichoptera) ..........

TANIDA, K.: Net structure and feeding ecology of some Japanese species of Hydropsyche

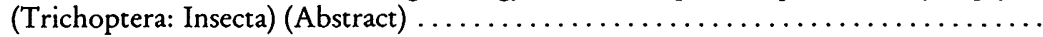

Ringelberg, J., Franeker, J. A. van \& Luttik, R.: Predation experiments with Chaoborus larvae on pigmented and translucent morphs of Acanthodiaptomus denticormis .......

Gíslason, G. M.: The life cycle and production of Simulium vittatum ZeTr. in the River

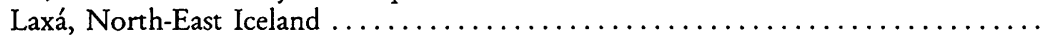

Vincent, B. \& Harvey, M.: Dynamique de deux populations du Gastéropode Bithynia tenta-

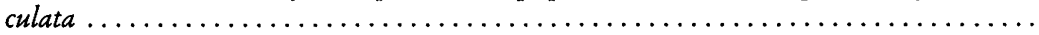

JoKINEN, E. H.: Comparative life history patterns within a littoral zone snail community ....

MasLin, J.-L.: Les peuplements de mollusques benthiques d'une lagune du Sud-Bénin (le lac A hémé): facteurs de leur répartition et impact des variations des conditions du milieu .

Cianficconi, F., Moretti, G. P. \& Pirisinu, Q.: Peuplements lotiques et lénitiques dans le système hydrographique de la Plaine de Rieti (Latium, Italie) .................

\section{Sediments}

Kawai, T., Otsukı, A., Aızakı, M. \& Nishikawa, M.: Phosphate release from sediment into aerobic water in a eutrophic shallow lake, L. Kasumigaura ..................

LöFGREN, S. \& RYDING, S.-O.: Apatite ionic products in different eutrophic sediments ....... 
LÖFGREN, S. \& RYDING, S.-O.: Apatite solubility and microbial activities as regulators of inter-

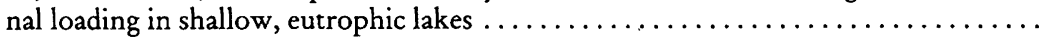

Boström, B., AHLGREN, I. \& BeLL, R.: Internal nutrient loading in a eutrophic lake, reflected in seasonal variations of some sediment parameters . . . . . . . . . . . . . . . . .

Peters, J. \& Liere, L. van: Dredging and groundwater-movement, effects on phosphorus

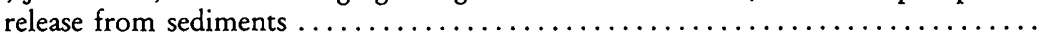

WiśnIEwskI, R. J. \& Planter, M.: Exchange of phosphorus across sediment-water interface (with special attention to the influence of biotic factors) in several lakes of different

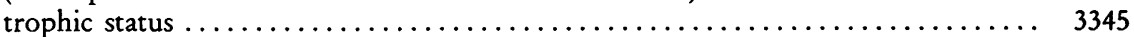

BARRoIN, G.: Relation phosphore - oxygène en zone profonde (Abstract) . . . . . . . . 3350

Marengo, G. \& PremazzI, G.: Biological availability of P-loads to Lake Lugano .......... 3351

\section{Special Topics}

BRIAND, F.: Structural singularities of freshwater food webs

VolOHONSKY, H.: Thermodynamic aspects of ecosystems steady state .................. Munawar, M. \& Munawar, I. F.: Seasonality of phytoplankton in the North American Great Lakes (Abstract)

DORGELO, J. \& HEYKOOP, M.: Avoidance of macrophytes by Daphnia longispina ..........

Report on the twenty-second congress...

Officers and list of members 


\title{
Reproductive strategies of two similar Daphnia species
}

\author{
Barbara E. TAYlor and Wilfried Gabriel
}

With 2 figures and 2 tables in the text

\section{Introduction}

Cladocerans, like many other invertebrates, continue to grow after beginning to reproduce, and their reproductive capability increases with size. What are the demographic consequences of this strategy of indeterminate growth? Here we present results of laboratory experiments in which we measured reproductive strategies of two large, similar cladoceran species, Daphnia pulex and D. pulicaria, under high and moderately limiting food conditions. From the experimental data, we calculated the intrinsic rates of increase $r$ for each reproductive strategy. We also estimated the effect on $r$ of changing the pattern of allocation of biomass to reproduction. The results suggest that the daphnid strategy may represent an evolutionary compromise between strategies that maximize $r$ and strategies that maximize total reproductive output.

\section{Methods}

The Daphnia were cultured in a flow-through system (a modification of the system described by LAMPERT 1976). Fresh culture medium dripped into the chamber, about $200 \mathrm{ml}$ in volume, at the upper end; old medium and waste material drained out through a mesh screen at the lower end. Culture medium flowed through the chamber at about $1.51 \cdot \mathrm{day}^{-1}$. The chambers were suspended in a water bath kept at $20.0^{\circ} \mathrm{C}$. Filtered lake water with Scenedesmus grown in chemostat culture was used as the culture medium. Fresh medium was prepared each day.

Daphnia pulicaria and $D$. pulex from laboratory cultures were used for the experiments. Both strains were supplied from the collection of Dr. V. HrbáČEK in Prague, Czechoslovakia. Neonates (0-18 hrs old) were used to begin the experiments. At the beginning of the reproductive period, each chamber contained about 10 animals. This number decreased during the experiment as animals were removed for dry weight measurements. Animals were counted, measured, and transferred to clean chambers every 2 days. Neonates were counted and discarded at each transfer. Body length was measured to the nearest $.04 \mathrm{~mm}$ from the top of the head to the base of the tail spine.

Animals were collected for dry weight measurements from the last prereproductive instar (instar $\mathrm{P})$ and each reproductive instar $(\mathrm{R} 1, \mathrm{R} 2, \ldots, \mathrm{Rn})$. So that the weights of somatic and reproductive tissue could be separated, animals were collected immediately after molting and egg production (in the case of reproductive animals). Animals to be weighed were killed with dilute unbuffered formalin, measured, and rinsed in distilled water. Eggs of ovigerous animals were removed from the brood chamber. Samples were placed in preweighed aluminum boats, dried for 1 hour at $102{ }^{\circ} \mathrm{C}$, and stored in a desiccator.

Experiments were run at $1 \mathrm{mg} \mathrm{C} \cdot 1^{-1}(D$. pulicaria, 5 replicate chambers; $D$. pulex, 3 replicates) and $.2 \mathrm{mg} \mathrm{C} \cdot \mathrm{l}^{-1}$ (D. pulicaria, 4 replicates; $D$. pulex, 4 replicates). Natural mortality was not significant in these experiments, and none of the experiments was run to the end of the natural lifespan of the animals.

Length-weight regressions (Table 1) were used to estimate biomass at each instar from the length measurements for each experiment. An average egg weight for each experiment was used to estimate reproductive biomass for each instar from the counts of eggs and neonates.

Growth $G$ was estimated by the difference between the average body weights for successive in stars. Biomass allocated to reproduction $\mathrm{R}$ was estimated by the weight of eggs produced after the 
Table 1. Length-weight regressions and egg weights. Best-fitting curve among linear, log-linear, ind $\log -\log$ relations is given. $\mathrm{L}$ is length in $\mathrm{mm}$, and $\mathrm{W}$ is weight in $\mathrm{mg}$. Sample size for the regressio is $\mathrm{n}$, and the correlation coefficient is $\mathrm{r}$. For the egg data, $\overline{\mathrm{x}}$ is mean weight per egg in $\mathrm{mg}, \mathrm{n}$ ishe sample size, and $\mathrm{s}_{\mathrm{x}}$ is the standard deviation.

\begin{tabular}{|c|c|c|c|c|c|c|c|}
\hline \multirow[t]{2}{*}{ Species } & \multirow{2}{*}{$\begin{array}{l}\text { Food } \\
\text { level } \\
\mathrm{mg} \mathrm{C} \cdot 1^{-}\end{array}$} & \multirow{2}{*}{ Regression equation } & \multirow[t]{2}{*}{ n } & \multirow[t]{2}{*}{$\mathrm{r}$} & \multicolumn{3}{|c|}{ Egg weight } \\
\hline & & & & & $\overline{\mathbf{x}}$ & $\mathrm{n}$ & s \\
\hline D. pulicaria & 1 & $\log W=2.514 \log L-5.180$ & 64 & .99 & .0028 & 11 & .003 \\
\hline D. pulex & 1 & $\log W=1.193 \mathrm{~L}-5.581$ & 29 & .99 & .0026 & 12 & .002 \\
\hline D. pulicaria & .2 & $\log W=1.628 L-6.996$ & 19 & .96 & .0027 & 4 & .001 \\
\hline D. pulex & .2 & $W=.033 \mathrm{~L}-.039$ & 24 & .91 & .0024 & 4 & .001 \\
\hline
\end{tabular}

molt to the following instar. Total biomass production $\mathrm{T}$ was estimated by growth $\mathrm{G}$ plu reproduction $R$. The proportion of biomass allocated to reproduction was estimated by $R / T$.

To analyse the demographic effect of the reproductive strategies, we calculated the intrinsicate of increase $r$ for each experiment. Assuming that production is a function of body weight, wecalculated fecundity schedules and $r$ values for two determinate growth strategies: 1) allocating̨the total production in instar $\mathrm{P}$ and all subsequent instars to reproduction, which results in concant body and clutch size; and 2) allocating the total production in instar $\mathrm{P}$ to growth, then allocatin the total production to reproduction in all subsequent instars, which results in constant bodyand clutch size after the 1 instar delay in reproduction. The total number of offspring $R_{0}$ was alsc calculated for each fecundity schedule. Data from 5 reproductive instars were used for each specis at $1 \mathrm{mg} \mathrm{C} \cdot 1^{-1}$; data from 4 reproductive instars, for each species at $.2 \mathrm{mg} \mathrm{C} \cdot 1^{-1}$. Increasing the umber of instars has a negligible effect on $r$, but increases $R_{0}$. Survivorship was assumed to be $1 \mathrm{f} e$ all calculations.

\section{Results}

Both Daphnia pulicaria and D. pulex at both food concentrations continued to gow for the duration of the experiments (Fig. 1). Reproductive output increased substantally

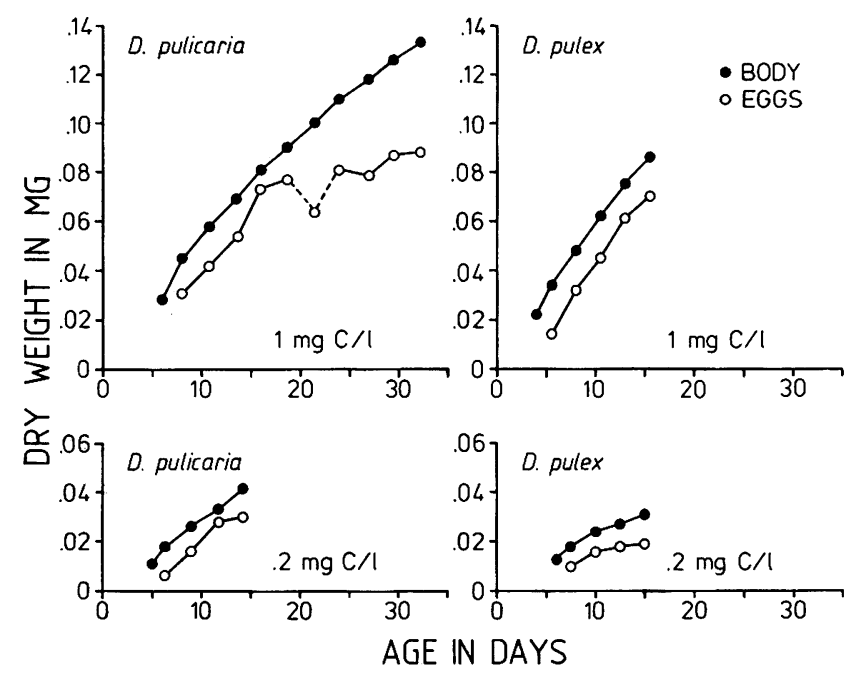

Fig. 1. Body weight and egg weight. Body weight is measured at the beginning of the instar. 
Fig. 2. Proportion of production allocated to reproduction.

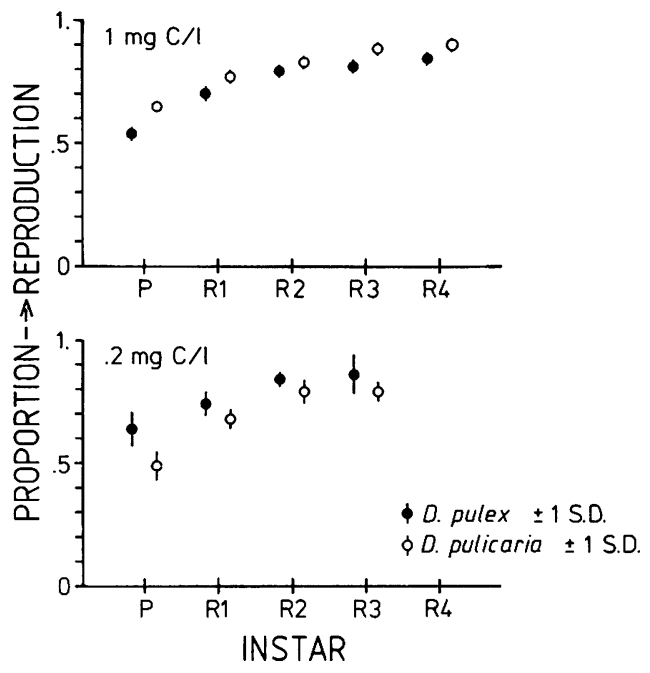

Table 2. Values of $r$ and $R_{0}$.

\begin{tabular}{|c|c|c|c|c|c|c|c|}
\hline \multirow[t]{3}{*}{ Species } & \multirow{3}{*}{$\begin{array}{l}\text { Food } \\
\text { level } \\
\mathrm{mg} \mathrm{C} \cdot 1^{-1}\end{array}$} & \multirow{2}{*}{\multicolumn{2}{|c|}{$\begin{array}{l}\text { Indeterminate } \\
\text { growth }\end{array}$}} & \multicolumn{4}{|c|}{ Determinate growth } \\
\hline & & & & \multicolumn{2}{|c|}{ 1) no delay } & \multicolumn{2}{|c|}{ 2) delay } \\
\hline & & $\mathrm{r}$ & $\mathrm{R}_{0}$ & $\mathrm{r}$ & $\mathrm{R}_{0}$ & $\mathrm{r}$ & $\mathrm{R}_{0}$ \\
\hline D. pulicaria & 1 & .300 & 98.7 & .315 & 84.5 & .296 & 121.6 \\
\hline D. pulex & 1 & .346 & 77.8 & .353 & 50.0 & .345 & 89.2 \\
\hline D. pulicaria & .2 & .251 & 29.8 & .248 & 19.6 & .261 & 36.6 \\
\hline D. pulex & .2 & .232 & 23.0 & .242 & 22.4 & .223 & 25.5 \\
\hline
\end{tabular}

in the earlier reproductive instars. At $.2 \mathrm{mg} \mathrm{C} \cdot \mathrm{l}^{-1}$ both species began to reproduce at much smaller body weights. Daphnia pulex delayed reproduction for several days at the lower food concentration, but $D$. pulicaria reproduced slightly earlier.

The reproductive strategies, as measured by the proportion of biomass allocated to reproduction at each instar, were very similar between species and food concentrations (Fig. 2). The general pattern shows moderate investment in reproduction at the last prereproductive instar $P$. This investment increases significantly in the subsequent 2 instars and remains fairly constant after instar R2. Values for instars R4 through R9 (not shown) for $D$. pulicaria range from .86 to .93 .

At $1 \mathrm{mg} \mathrm{C} \cdot 1^{-1}$ the shorter juvenile period gives $D$. pulex a higher $\mathrm{r}$ value than $D$. pulicaria, although $D$. pulicaria has higher fecundity at each instar (Table 2). At $.2 \mathrm{mg} \mathrm{C} \cdot 1^{-1}$ both higher fecundity and a shorter juvenile period contribute to the higher $r$ value for D. pulicaria.

The $r$ calculations also show that in each case one of the determinate growth strategies gives a higher $r$ value than the value calculated from the experimental data, which represent the natural strategy of indeterminate growth. For $D$. pulicaria at $1 \mathrm{mg} \mathrm{C} \cdot 1^{-1}$ and for $D$. pulex at both food concentrations, determinate growth strategy 1 (no delay in reproduction) gives the highest $\mathrm{r}$ values. For $D$. pulicaria at $.2 \mathrm{mg} \mathrm{C} \cdot 1^{-1}$, determinate growth strategy 2 ( 1 instar delay in reproduction) gives the highest $r$ value. In all cases $R_{0}$ 
values are lowest for determinate growth strategy 1 , higher for the natural indeterminate growth strategy, and highest for determinate growth strategy 2. These values underestimate $\mathrm{R}_{0}$ for the natural lifespan of the animal, but show the same rank order as values calculated from longer sequences of data.

\section{Discussion}

The relatively higher intrinsic rates of increase for Daphnia pulex at the high food concentration and for $D$. pulicaria at the moderate food concentration are consistent with the results of HRBÁČEK (1977). According to his interpretation, D. pulex is more " $r$-selected", and D. pulicaria is more "k-selected". The similarities of allocation of biomass to growth and reproduction in these two species suggest that the differences in $r$ values are not caused by differences in this component of the reproductive strategy. The differences lie in the age and size at the beginning of the reproductive period and in the relations between production and body size.

Under constant environmental conditions, the reproductive strategy that maximizes $r$, within the constraints imposed by physiology and morphology, will be the optimal strategy. Under other conditions, maximizing $r$ may not be optimal. For example, when the growing season is limited and the population does not reach stable age distribution, a strategy that maximizes the total reproductive output $R_{0}$ may be better (see GABRIEL 1982).

For both species at both food concentrations, determinate growth strategies estimated from the production data produced higher values of $r$ than did the experimentally measured strategies of indeterminate growth, suggesting that indeterminate growth does not maximize $r$. However, the $r$ values for indeterminate growth are only slightly lower than the values for the best determinate growth strategies, and the $R_{0}$ values for indeterminate growth are higher, excepting the case of $D$. pulicaria at $.2 \mathrm{mg} \mathrm{C} \cdot 1^{-1}$. We speculate that the indeterminate growth strategy may be an evolutionary compromise: at a low cost, in terms of the reduction in $r$, the animal substantially increases the total number of young produced. The advantage of this compromise may be substantial, given the strong seasonality of many of the environments where cladocerans are found.

\section{Acknowledgements}

This work was carried out while BET was supported by a research fellowship from the MaxPlanck-Gesellschaft to work in AG Planktonökologie at the MPI für Limnologie at Plön. W. LAMPERT offered valuable advice at all stages of the project, M. MORT commented on the manuscript, and H. Claussen and M. Volquardsen maintained the stock cultures of Daphnia and Scenedesmus.

\section{References}

GABRIEL, W., 1982: Modelling reproductive strategies of Daphnia. - Arch. Hydrobiol. 95: 69-80.

HRBÁČEK, J., 1977: Competition and predation in relation to species composition of freshwater zooplankton, mainly Cladocera. - In: Aquatic Microbial Communities: 307-353, ed. J. CAIRNS, Jr.

LAMPERT, W., 1976: A directly coupled, artificial two-step food chain for long-term experiments with filter-feeders at constant food concentrations. - Marine Biology 37: 349-355.

Authors' addresses:

Arbeitsgruppe Planktonökologie, Max-Planck-Institut für Limnologie, Postfach 165, D-2320 Plön, Fed. Rep. Germany; present address of B. E. TAYLOR: Savannah River Ecology Laboratory, Drawer E, Aiken, South Carolina 29801, U.S. A. 